Maksim Mojsiejew • Максим Моисеев

Muzealne Stowarzyszenie "Muzeum Moskwy"

ORCID ID: 0000-0003-0421-8982
OBLICZA WOJNY

TOM $3 \cdot$ MIASTO I WOJNA

ŁÓDŹ 2021 • ISBN 978-83-8220-556-5 • s. 81-97

https://doi.org/10.18778/8220-556-5.05

\title{
СЛОБОДА МОСКОВСКИХ СТРЕМЯННЫХ СТРЕЛЬЦОВ. ДАННЫЕ АРХЕОЛОГИЧЕСКИХ РАСКОПОК
}

\begin{abstract}
Streszczenie. Artykuł poświęcony jest osadzie strzelców pułku strzeleckiego, który znajdował się w Moskwie w pobliżu Kremla na prawym brzegu rzeki Neglinnej. Osada została odkryta przez moskiewskich archeologów w 1990 r. Naukowcy znaleźli wówczas fragmenty infrastruktury miejskiej, budynki mieszkalne, wyposażenie gospodarstwa domowego. Odkrycia te nigdy nie stały się jednak przedmiotem specjalnych badań poświęconych warunkom życia strzelców moskiewskich. Niniejszy artykuł jest próbą wstępnego zbadania tej problematyki. W pracy podano krótką historię wykopalisk na Placu Maneżowym (Мане́жная пло́щадь) w latach 19931997, przeanalizowano podstawową historiografię poświęconą strzelcom. Do badań pozyskano archeologiczną dokumentację terenową, albumy znalezisk. Analiza przedmiotów pozwoliła dojść do wniosku, że strzelcy pułku strzeleckiego znajdowali się blisko szczytu w hierarchii mieszkańców Moskwy.
\end{abstract}

Słowa kluczowe: Moskwa, strzelcy, mieszczanie, osada, archeologia

1990-е гг. в истории Москвы отметились не только бурными событиями в политической и экономической жизни города, но и большим научным событием. Полем Аля археологических работ стала бывшая площадь 60-летия Октября, получившая в новой России новое имя - Манежной. Раскопки проводились центром археологических исследований г. Москвы в течение четырех мет - с 1993 по 1997 год. Вскрытый мощный культурный слой, достигавший более семи метров, бым насыщен интереснейшими находками, относящимися к разным периодам истории города - глиняной и стекмянной посудой, медными и серебряными монетами, предметами вооружения, украшениями, детскими игрушками, печными изразцами. 
Археологам удалось раскрыть фундаменты каменной застройки XVIXIX вв., выявить деревянные мостовые, срубы домов и колодцев, трубы Аренажной системы более раннего времени - XVI-XVII вв. Среди крупных объектов, обнаруженных археологами, были Моисеевский женский монастырь и его кладбище, слобода Стремянного стрелецкого полка и устои мостов через реку Неглинную. Вокруг устоев Воскресенского моста XVII-XVIII столетий был устроен Музей Археологии Москвы. Все это позволико преАставить планировку и застройку Аревнего района Москвы - Нижнего Занеглименья, растянувшегося по берегу некогда протекавшей здесь реки Неглинной, воссоздать быт его населения. Важнейшее место среди более сотни выявленных архитектурных сооружений занимают каменные устои Воскресенского моста. Исследование культурного слоя Манежной площади дало возможность понять особенности развития этого московского микрорайона. Теперь стало понятно, что хотя первые поселения здесь появцяются еще в домонгольское время, но активно осваиваться это место, стало позднее, чем весь остальной занеглименский посад, а именно во 2-ой половине XVI века. КогАа именно здесь появляется слобода стремянных стрельцов сказать сложно. На так называемом „Сигизмундовом плане” Москвы 1610 г., отражающем реалии рубежа XVI-XVII вв., на этом участке отмечена некая застройка, которая, можно предположить, относится к церкви Моисея БоговиАца, четко изображенной на плане. Быть может это те самые богадельни построенные в 1599/1600 г. Аля нищих мирян ${ }^{1}$. Отталкиваясь от сведений XVII и начала XVIII вв., нам известно, что слобода начиналась от строений возникшего позднее Моисеевского монастыря (включившего в себя те самые богадельни) и простиралась до церкви Николая Чудотворца в Сапожке, которая располагалась напротив известной Кутафьей башни. Именно эта церковь считалась приходской аля стрельцов Стремянного полка. После успешного бунта московские стрельцы выстроили ей новое здание, которое было освещено 19 октября 1682 г. $^{2}$ Итак, слобода Стремянного полка оказалась ограничена 2-я церквами и на современном плане ее территория может быть опредемена как местность, примегающая к зданию Манежа и сам Манеж.

\footnotetext{
${ }^{1}$ Пискаревский летописеи, [w:] Полное собрание русских летописей, Москва 1974, s. 202.

2 А.Ф. МАлиновсКий, Обозрение Москвьь, Сост. С.Р. АолговА, Москва 1992, s. 143.
} 
Стремянной стрелецкий полк составная часть стрелецкого войска и Аля его истории характерны общие закономерности развития этого вида войска. По наблюдениям И. А. Беляева, русское войско уже со времен Ивана III начинает принимать „более постоянное устройство”, в XVII веке же уже пережило системную реформу. При Михаиме Федоровиче оно подразделялось на конницу, пехоту и артилмерию 3 . Реформу пехотного войска автор относим ко времени Ивана Грозного, появцение стрельцов датировал 1550 г. и связывал с выявленными недостатками русской пехоты в войнах с Польшей и Швецией ${ }^{4}$. Набор в стрельцы происходиц из вольных жителей, „которые еще не были в тягле”. И. А. Бе-

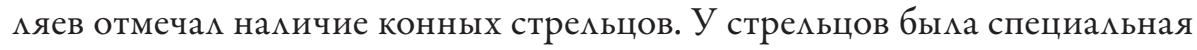
форма разцичная у каждого полка, а также знамена, барабаны и пушки у каждого полка свои. Служба стрельцов была пожизненной, набор же „проходиц за круговою порукою”. Необходимость в рекомендациях „старых добрых стрельцов” при поступцении в полк Аиктовалась достаточно широкими Аьготами, Аарованными правительством стрельцам. Отставные стрельцы отсыцались в монастыри или оставались в своих семействах с получением содержания от монастырей5

И.А. Беляев отметил разделение стрельцов на городовых и московских, среАи последних он выделим Стремянной полк, обязанный сопровождать царя или царицу. Служба в московских полках носила привикегированный характер. В течение XVII века количество московских полков не было неизменным. Сначала было 12 полков, в 1672 г. Алексей Михайлович прибавия еще несколько, довеАя их число, Ао 14, в 1683 г. - 19 полков, а в годы соправительства царей Ивана и Петра - 28 полков. Каждый московский полк имец свой номер, повышение в нем считалось наградой за заслуги. Численность московских полков нельзя увязать с количеством полков, так как они числом неравны: могли насчитывать как 1200 человек, так и менее $1000^{6}$.

${ }^{3}$ И. БЕляев, О русском войске в царствование Михаила Федоровича и после его, до преобразований, сделанных Петром Великим, Москва 1846, s. 3.

${ }^{4}$ И. БЕ $Я$ ЯЕВ, op. cit., s. 44-46.

5 Ibidem, s. 46-51.

${ }^{6}$ Ibidem, s. 52-57. 
Службы стрельцов разделял на военные и мирные, к мирным службам относим полицейские функции, а московские стрельцы участвоваци еще в Аипломатических церемониях. Московские службы полки несли понедельно, имелась еще и городовая, когда их посылали на службу в разные города на два года, после 1682 г. срок городовой службы сокращен на один год. Ко всему прочему, в мирное время проводились учения и смотры ${ }^{7}$.

ГАавным местом управления стрецьцами выступал Стрелецкий приказ, в городах же они подчиняцись местным воеводам и наместникам. Непосредственными делами полка занималась полковая съезжая изба. Возглавця ее полковой голова, помогани ему мцадшие командиры: пятисотники, сотники и далее вплоть до десятника. И.А. Беляев указывал, что стрелецкие командиры от головы до сотника назначацись „из приАворных чиновников ими из кучших Аворянских фамимий”, пятидесятники и десятники выбирались из рядовых стрельцов. В 1681 г. произошло изменение в стрелецкой терминологии. Головы стаци называться полковниками, пятисотники - подполковниками, сотники - капитанами. После стрелецкого восстания 1682 г. стрельцы были переименованы в наАворную пехоту, управцяться же они стаци приказом надворной пехоты и Судным приказом ${ }^{8}$.

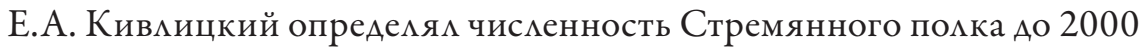
ч. Историк утверждац, что отставные стремьцы, а так же их жены и дети убитых и попавших в плен продолжаци жить в стрелецких слободах служба стрельцов была пожизненной и наследственной. В мирное время стрельцы несли полицейскую службу, а также учимись стрельбе и т. п. Указывац на наличие определенных мьгот распространявшихся на торгово-ремесленную деяте ьность стремьцов и их судебные иски'

C начала XX века историки уделяют большое внимание социальным Авижениям, „стрелецкая” тематика не стала искиючением. С.В. Бахрушин рассмотрел участие стрельцов в московском восстании 1648 г. $^{10}$

7 Ibidem, s. 49, 54, 55, 81.

${ }^{8}$ Ibidem, s. 78-81.

9 Е.А. Кивцицкий, Стрельщьь, [w:] Энщиклопедический словарь Брожгауза и Эфрона, Санкт-Петербург 1901, t. 62 (ХXXIa): (Статика-Судоустройство), s. 848.

${ }^{10}$ С.В. БАХрУшин, Московский мятеж 1648 года, [w:] Сборник статей в честь Матвея Кузьмича Аюбавского, ПетрограА 1917. 
Попыткам втянуть в антигосударственный переворот стрецьцов Стремянного полка, предпринятым бывшим полковником этого полка думным Аворянином Иваном Цыклером в 1697 г., посвятим специацьную работу М.М. Богословский ${ }^{11}$.

Сужение стрелецкой проблематики до участия в антиправитецьственных Авижениях XVII столетия отвечала потребностям момента и была связана с бурными событиями начала XX века. Со становцением советского общества, стабимизацией роли государства произошло возвращение к традиционным Аля русской историографии темам. Возросла роль историков близких к „государственному” направлению отечественной исторической науки и как следствие стрецьцы вновь стали фигурировать как самодостаточное явление. Среди советских историков, занимавшихся пробцематикой военной истории допетровской России, следует выделить С. А. Марголина и А.В. Чернова.

В 1940-х годах С.А. Марголин выпустиц серию работ, посвященных стрелецкому войску. В ходе анализа этого исторического явления он пришел к выводу, что стрельцы являлись более совершенным, по отношению к Западной Европе, пехотным войском, вынужденным действовать „...в рамках общей военной организации, отличавшейся большим перевесом чисто феодацьных элементов, чем та, в которой действоваца профессионацьная наемная сима Западной Европы"12. В отношениях стрельцов с посадом автор указац на „противоречивое сочетание стреммения к обособлению слободы и тенденций, подчинявших ее общим условиям жизни города". Серьезным успехом С. А. Марголина стало

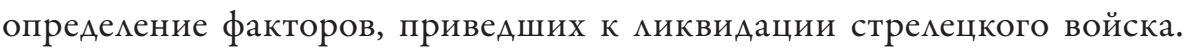
Во-первых, это тесная связь с посадом, и как следствие вовлеченность стрельцов в антиправительственные Авижения. Во-вторых, расширение территории Московского государства, вызвавшие сАвиги „в распределении его военных сим, подрываци основы стремецкого быта”. В-третьих, появление кремниевых ружей, привело к появлению Аинейной тактики.

${ }^{11}$ М.М. Богословский, Заговор Цьклера, [w:] Сборник статей по русской истории, посвященных С.Ф. Платонову, Петербург 1922, s. 330-340.

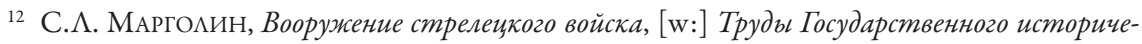
ского музея Вып. ХХ: Военно-исторический сборник, Москва 1949, s. 93. 
В результате если фитильные ружья требовали стрелка-специалиста, то теперь потребовацась уже новые формы военной организации ${ }^{13}$.

Существенным вкцадом в историографию „стрелецкой проблемы” по праву считаются работы А.В. Чернова. Автор относим появление стрелецкого войска к 1545 г., а в 1550 г. были образованны „выборные” стрельцы ${ }^{14}$. В ходе своего исследования А.В. Чернов создал концепцию развития и угасания стрелецкого войска, Аогично объяснявшего военные реформы Петра I. С точки зрения исследователя стрельцы в течение XVII века превращались в военно-полицейскую силу и теряли свое военное значение. Крайне отрицательно на их боевое значение сказалось право занятия торгово-ремесленной деятельностью ${ }^{15}$.

В итоге концепция истории стрелецкого войска, преАложенная А.В. Черновым, стала основной, что и отразилось в фундаментальном ком ективном труде „Очерки истории СССР”, в котором соответствующий раздем он написа ${ }^{16}$.

ОАновременно с военными исследованиями, посвященными „стрецецкой проблематике”, продолжалось и изучение участия стрельцов в социальных движениях в России в XVII веке. А.А. Новосельский и А.Н. Сперанский отметили, что стрельцы сыграли важную роль на начальном этапе московского восстания 1648 г. ОАнако роль стрельцов в мятеже авторы ограничили: во-первых, стрельцы Стремянного полка остались верны правительству, представители же Аругих полков, получив удержанное жалованье, откололись от восставших ${ }^{17}$. С.К. Богоявленский и Н.В. Устюгов в ходе изучения стрелецкого восстания 1682 г. пришли к однозначному выводу о деградации стремецкого войска и утере им боевой силы ${ }^{18}$.

13 С. $\Lambda$. МАРГОАИН, ор. cit., s. 99-101.

14 А. В. Чернов принял указание К. Маркса об учреждение стрелецкого войска в 1545 г. как методическое. А^я его обоснования он воспользовался в основном очень сложным памятником - „Казанской историей”, ценность которого как источника до сих пор оценивается весьма скептически. См.: А.В. Чернов, Вооруженные силь Русского государства в XV-XVII вв. С образования иентрализованного государства до реформ при Петре I. Краткий очерк, Москва 1954, s. 44-48.

${ }^{15}$ Ibidem, s. 85-86, 127.

16 Очерки истории СССР. Период феодализма конеи XV - начало XVII в., Москва 1955, s. 328-333, 439-448.

17 Ibidem, s. 226-234.

18 Ibidem, s. 326-334. 
Таким образом, к 1950-м годам было сформулировано две концепции, объяснявшие общий ход и упразднение стрелецкого войска в конце

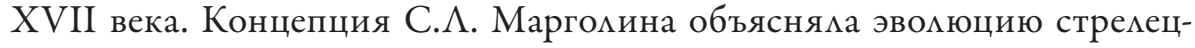
кого войска с точки зрения развития оружия, а А.В. Чернов - процесса превращения стрелецкого войска в военно-полицейские формирования. Необходимо отметить, что концепция А. В. Чернова получима в российской историографии наибольшее признание.

Итак, стрельцы Стремянного полка оказались самым привилегированным и верным вцасти подразделением московских стрельцов, при-

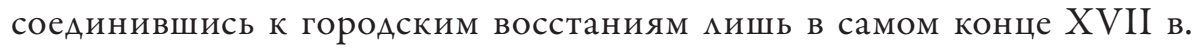
Среди их гражданских занятий оказалась работа площадными подьячими. С середины XVI в. в Московской Руси существовац институт площадных подьячих, выполнявший до конца XVII в., „главным образом некоторые нотариацьные функции в соответствующих, конечно, тому времени формах"19. Именно стремянные стремьцы составцяли самую элитарную группу площадных подьячих, будучи подьячими Ивановской площади (площадь в Московском Кремле, там, где размещались здания приказов). Контора их помещалась вблизи приказов на площади около колокольни Ивана Вемикого в здании, носившем название „палатки Ивановской площаАи” ими просто „Ивановской пацатки”. По мнению М.Ф. ЗАотникова, стрельцы исполняли эту работу и ранее (еАва $и и$ не с конца XVI в.), а после успешного стрелецкого восстания 1680-х гг. Ивановская площадь оказалась полностью в ведении Стрелецкого приказа. Работая площадными подьячими, стрельцы сохраняли свое жалованье. Работа на площади, особенно в организации Ивановской площади было очень выгодным, и можно предположить, что работа становимась наследственной и образовывацись „династии” площадных подьячих ${ }^{20}$. В целом, можно отметить, что стрельцы Стремянного полка состав я $и$ зажиточную прослойку городских жителей и можно полагать быми связаны с верхушкой московского посада. Все эти наблюдения в определенной степени подтверждают и археологические находки.

19 М.Ф. ЗАОтников, Подьячие Ивановской площади (К истории нотариата Московской Руси), [w:] Сборник статей, посвященных Александру Сергеевичу Ааппо-Аанилевскому, ПетрограА 1916, s. 82.

${ }^{20}$ Ibidem, s. 107-118. 
Непосредственно при раскопках Манежной площади территория Стремянной слободы попама в раскопах 9, 17, а также в нескольких шурфах. Слои XVII в. были симьно перемешаны и перекрыты застройкой XVIII-XIX вв. Именно поэтому затруднена надежная датировка найденных предметов и строгая атрибуция принадлежности их именно стрельцам, а не мюдям, жившим здесь в XVIII в. В ходе работ были выявлены остатки городской инфраструктуры XVII в.: мостовые, колодцы, а также эмементы жимой застройки. В ходе расчистки были выявлены предметы, которые позволяют реконструировать быт стрельцов Стремянного полка. Среди находок значительную часть составцяют печные изразцы, среди которых есть и терракотовые („красные”), и муравленные (зеленые). Сюжетно преобладают сцены осаА, штурмов, сражений ${ }^{21}$. Приверженность к мимитарной тематике не вызывает удивления и можно полагать сознательность выбора. Археологи находици слюдяные оконницы, искусно вырезанные детаци домов, кроме этого, в культурном слое встречацись фрагменты дорогого западноевропейского импорта, а именно так называемый „каменный рейнский товар”.

Кроме бытовых предметов, археологи нашии размичные фрагменты вооружения. Среди них выделяется своей сохранностью кожаная седемьная кобура - ольстер, которая выступает вещественным подтверждением того факта, что стрельцы Стремянного полка были конными. Хотя это, конечно, не кавалерия в полном смысле слова, а скорее пехота, посаженная на мошадей. Была выявлена гарда сабли с искусным раститецьным орнаментом, а также нескоцько ножей и кожаных ножен. Ружейные замки, кремни, кресало с отверткой, пули и пушечные ядра. Все эти предметы отмично им юстрируют особенности Стремянного полка и его службы. Как известно стрельцы этого полка исполняли не только функции охраны царя и его семьи, но также использовацись при церемониацьной встрече иностранных послов. Быми у них на вооружении и пушки. В це-

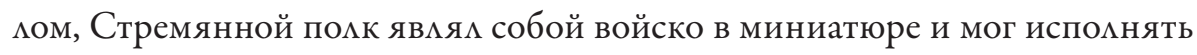
разнообразные функции.

Археологические данные рисуют быт стрельцов Стременного полка, как вполне состоятельный. Их дома были искусно слеланы, украшены резьбой, вероятно имели 2-а этажа. Окна быми затянуты слюдой, а не

21 Музей Москвы, АПА 4/5, Манежная площадь - 1993 г., № 222-225. 


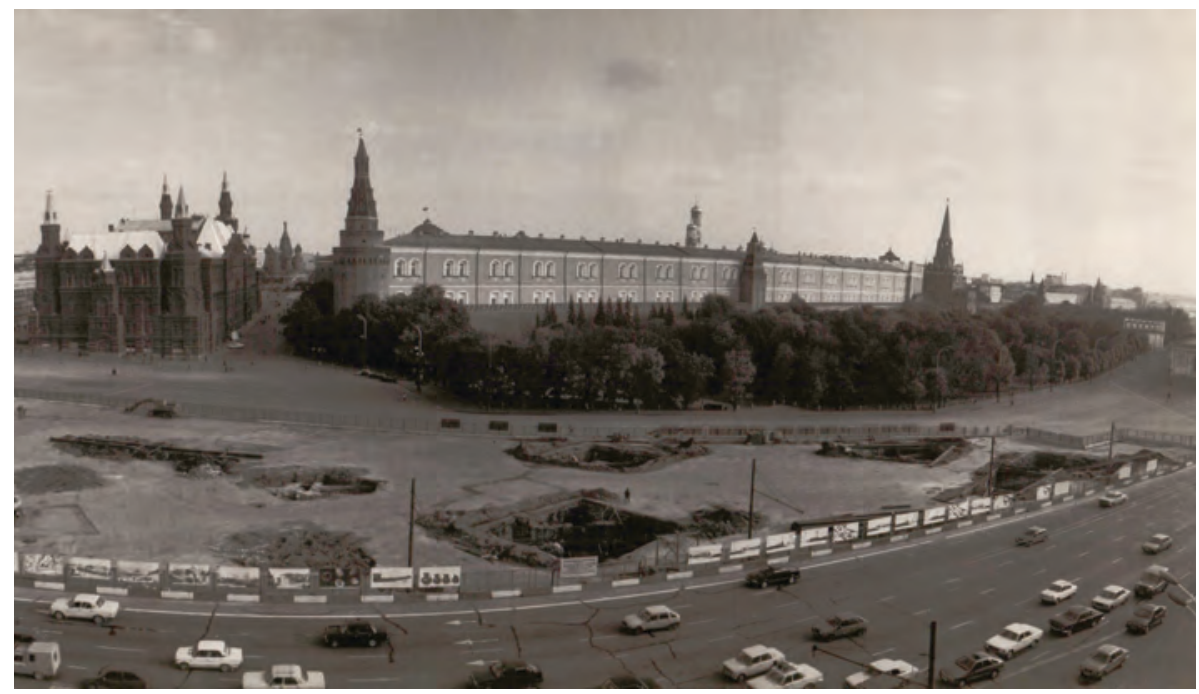

Рис. 1. Раскопки на Манежной площади 1993-1996 гг. Общий вид (Архив Департамента Культурного Наследия)

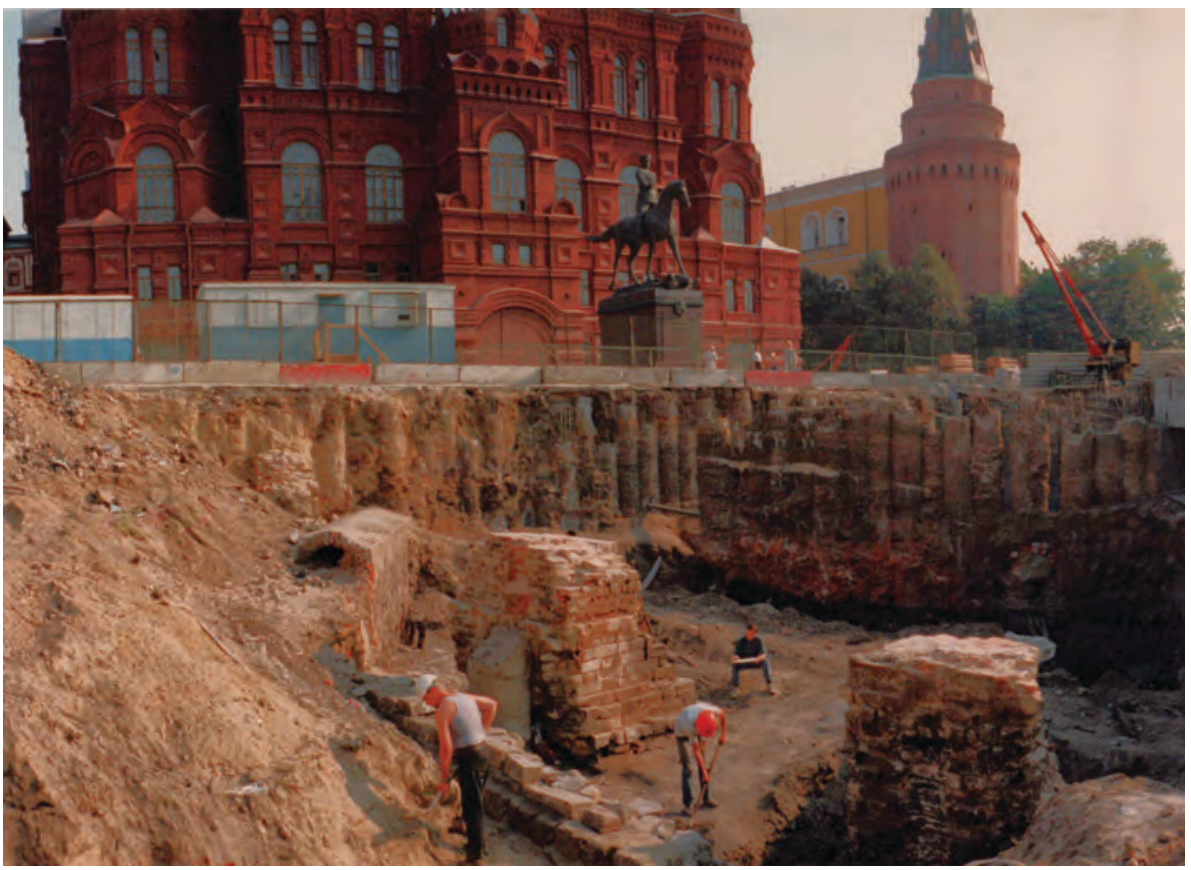

Рис. 2. Раскопки на Манежной площади 1993-1996 гг. Вид на выявленные устои Воскресенского моста (XVIII в.) через реку Неглинную (Архив Департамента Культурного Наследия) 


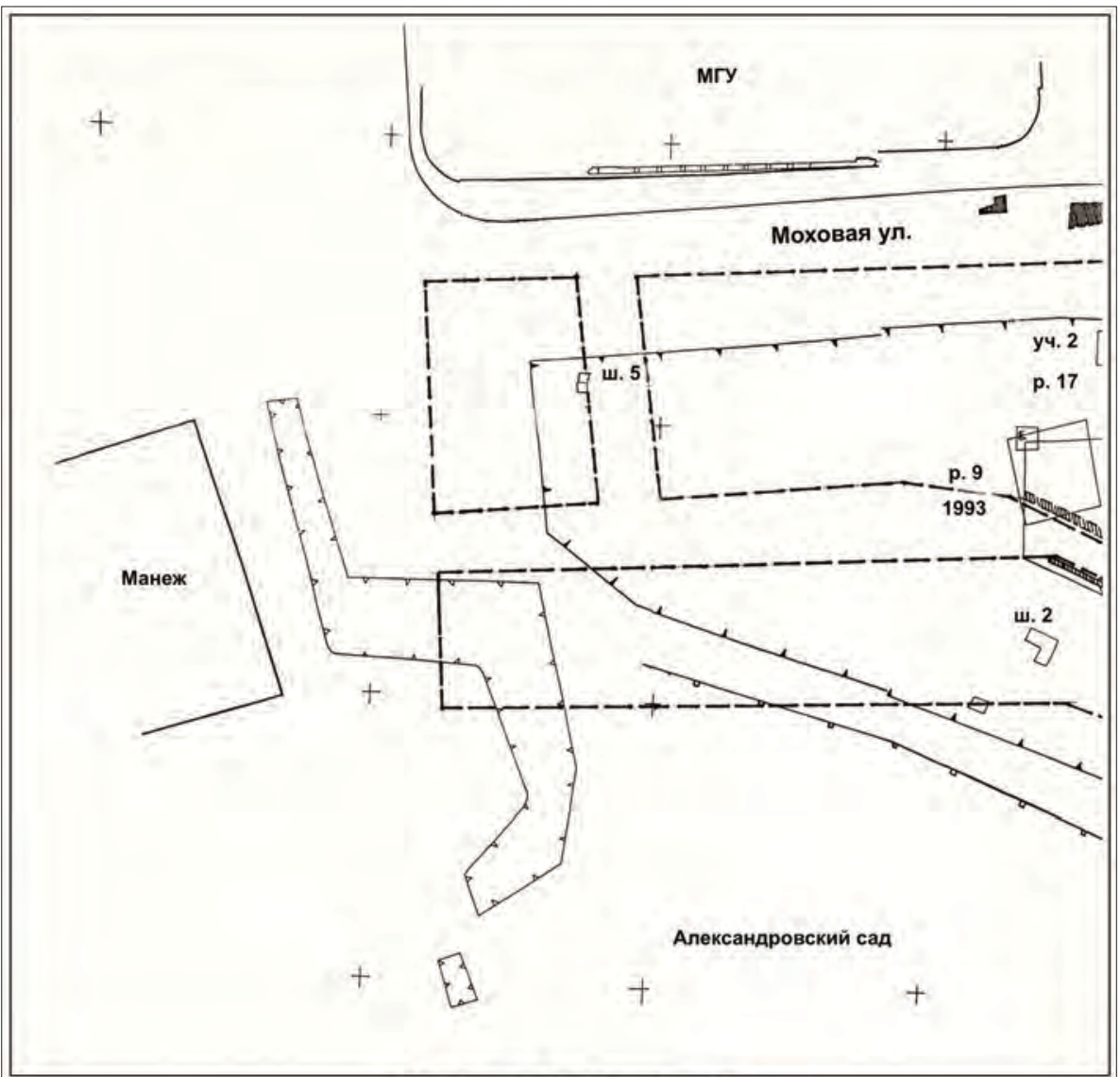

\section{УСЛОВНЫЕ ОБОЗНАЧЕНИЯ}

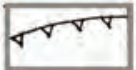

траншея (зона наблюдений 1994 r.)

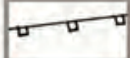

забор

पIIII.

кирпичная и белокаменная кладки
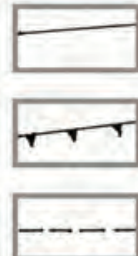

котлован (зона наблюдений 1994 г.)

котлован (зона наблюдений 1994 г. 1995 r.)

граница застройки квартала, сформировавшаяся к началу 20 в.

деревяные мостовые

(сооружения)

Рис. 3. Фрагмент ситуационного плана с отмеченными раскопами, захватившими территории слободы стрельцов Стремянного полка (Архив Департамента Культурного Наследия) 


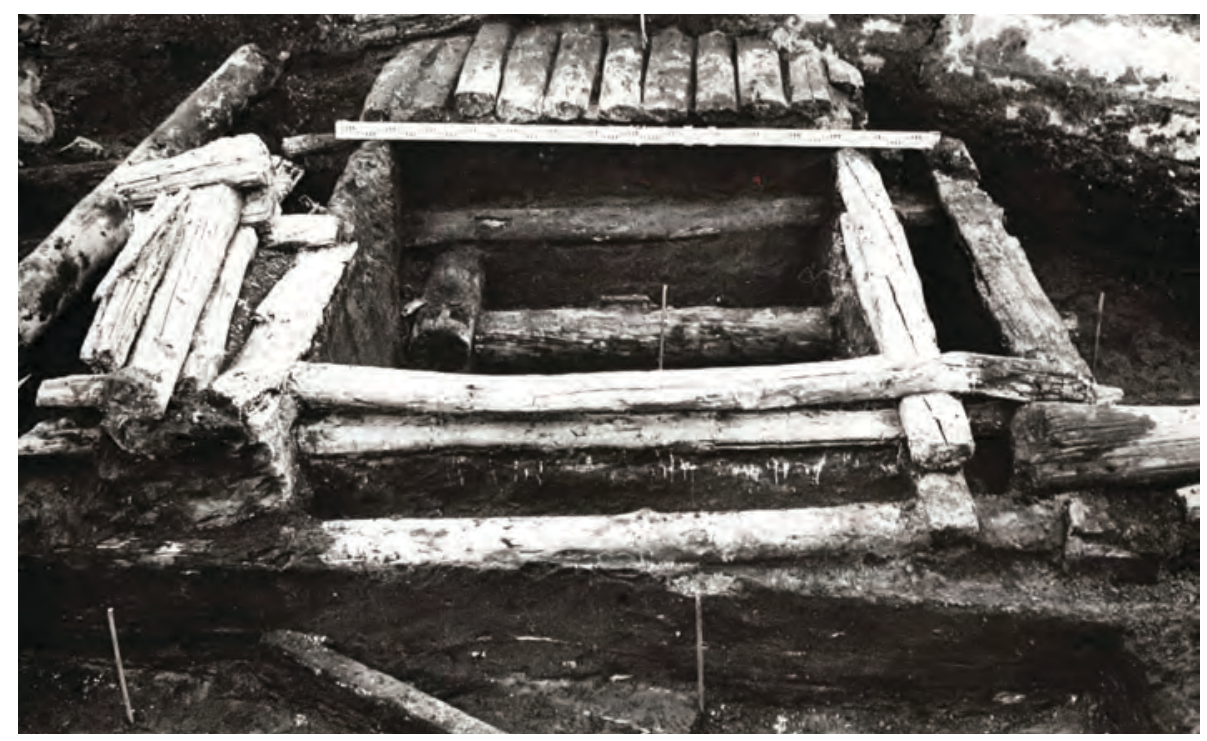

Рис. 4. Элементы городской инфраструктуры. Колодец (Архив Департамента Культурного Наследия)

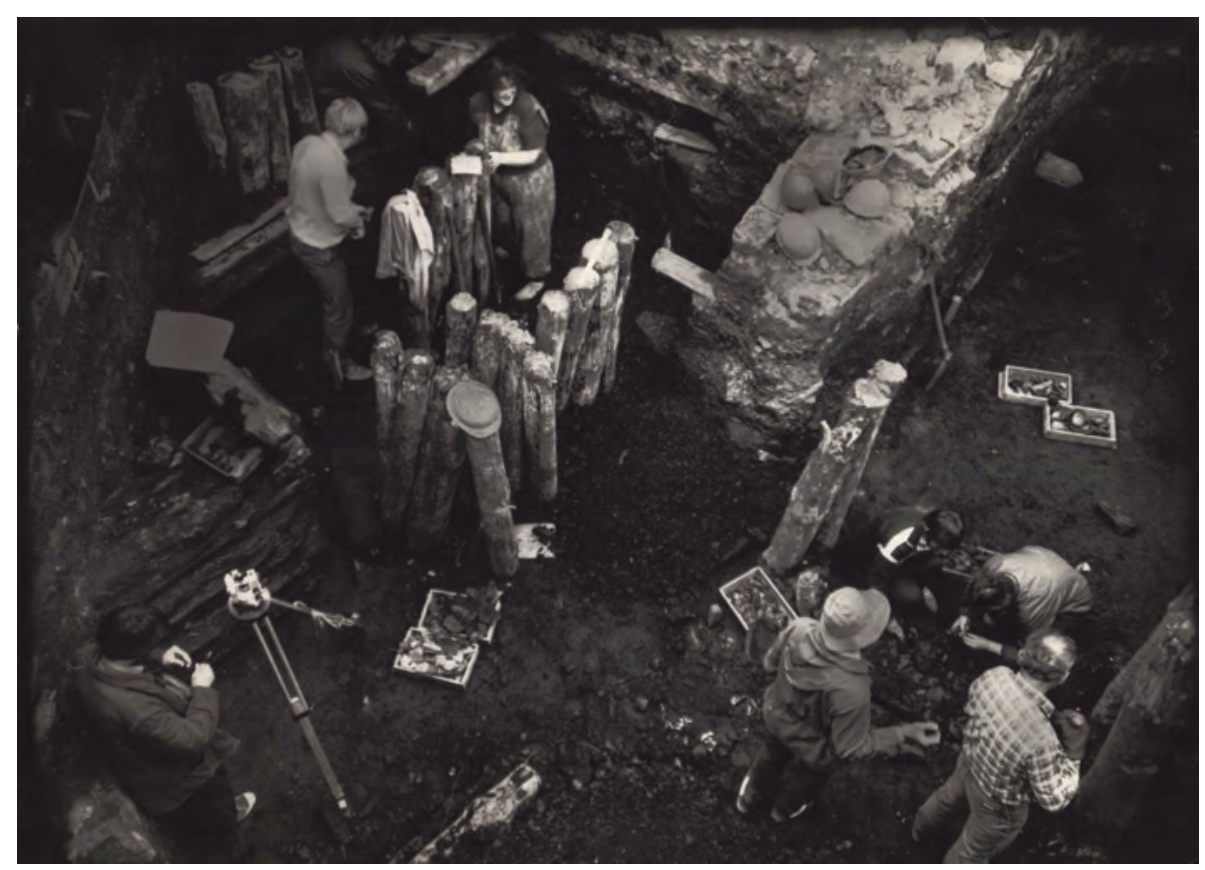

Рис. 5. Элементы городской инфраструктуры (Архив Департамента Культурного Наследия) 


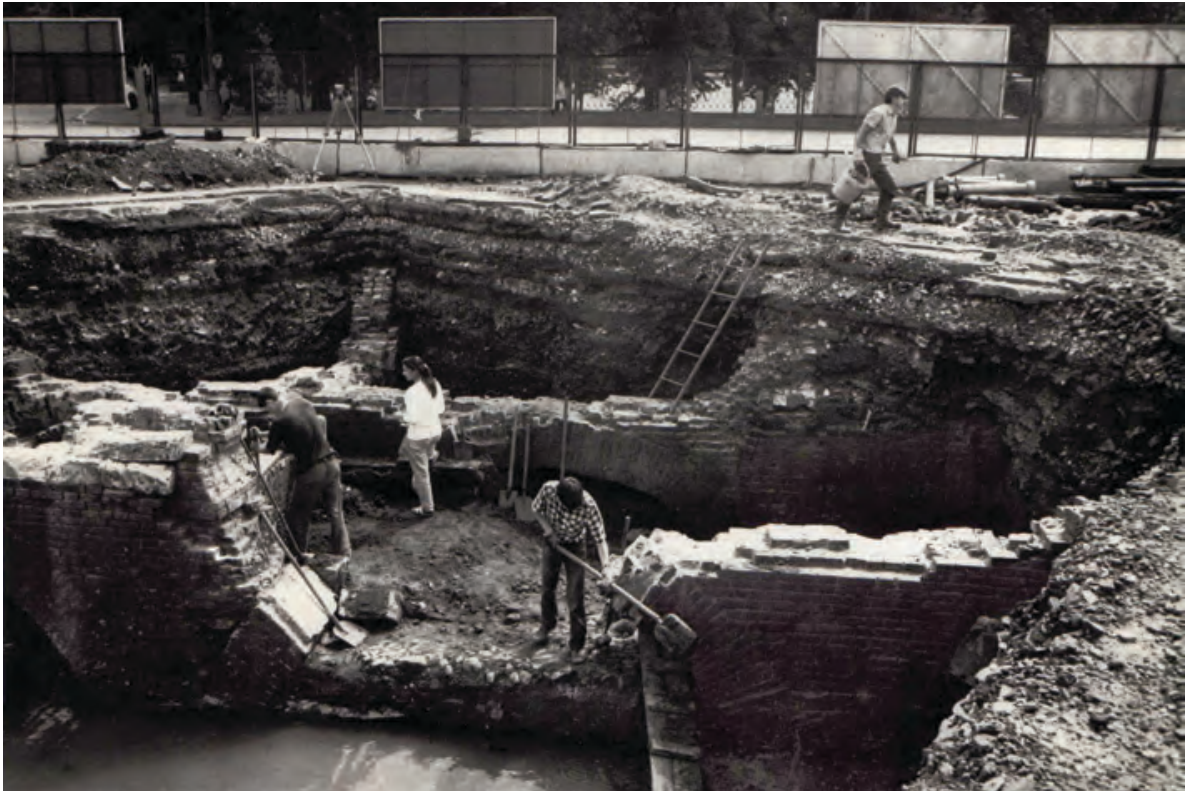

Рис. 6. Элементы поздней городской застройки, перекрывающие более ранние культурные слои (Архив Департамента Культурного Наследия)

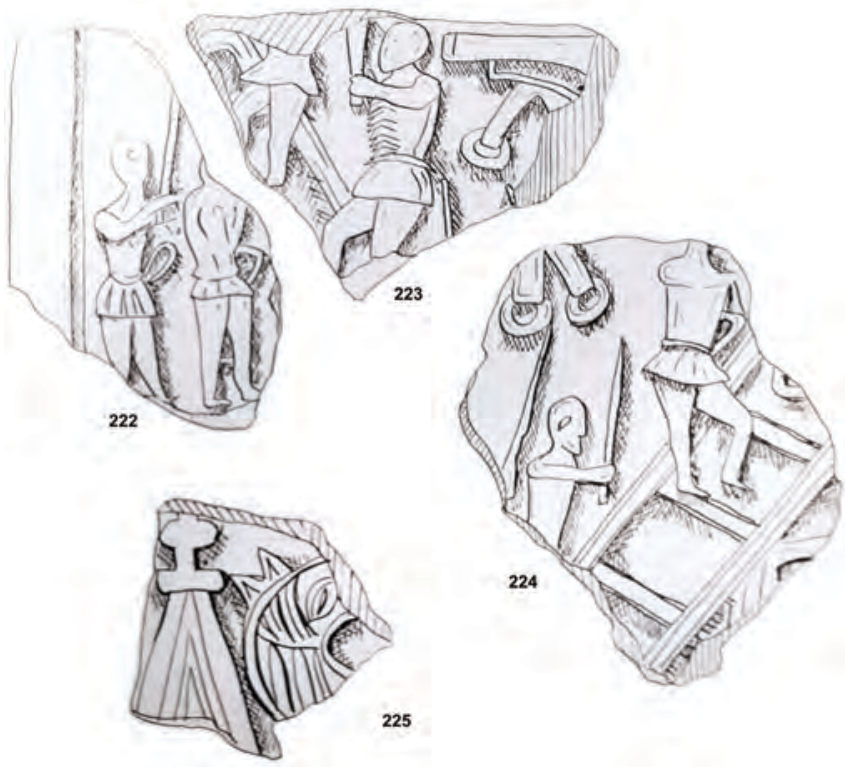

Рис. 7. Зарисовки печных изразцов. Археологическая полевая документация (собрание Музея Москвы) 


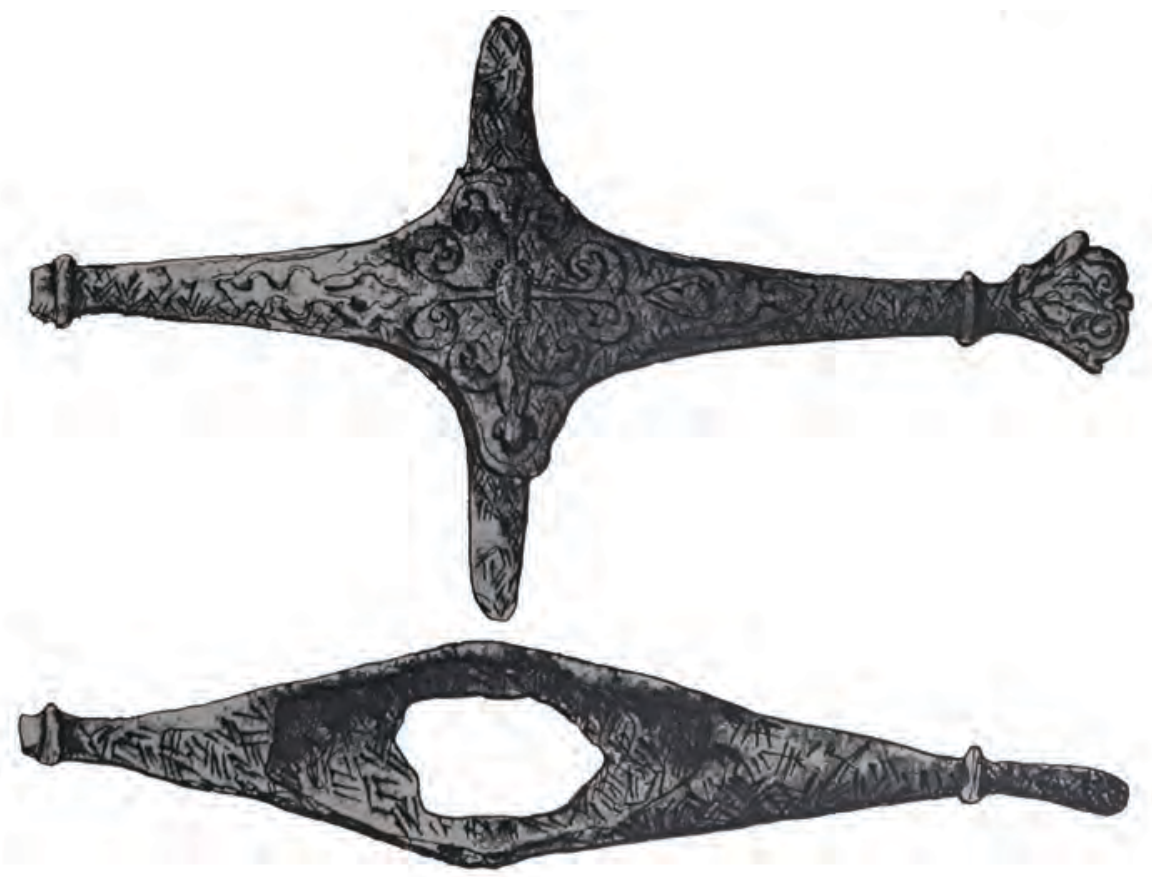

Рис. 8. Графическая фиксация перекрестия сабли. Археологическая полевая документация (собрание Музея Москвы)
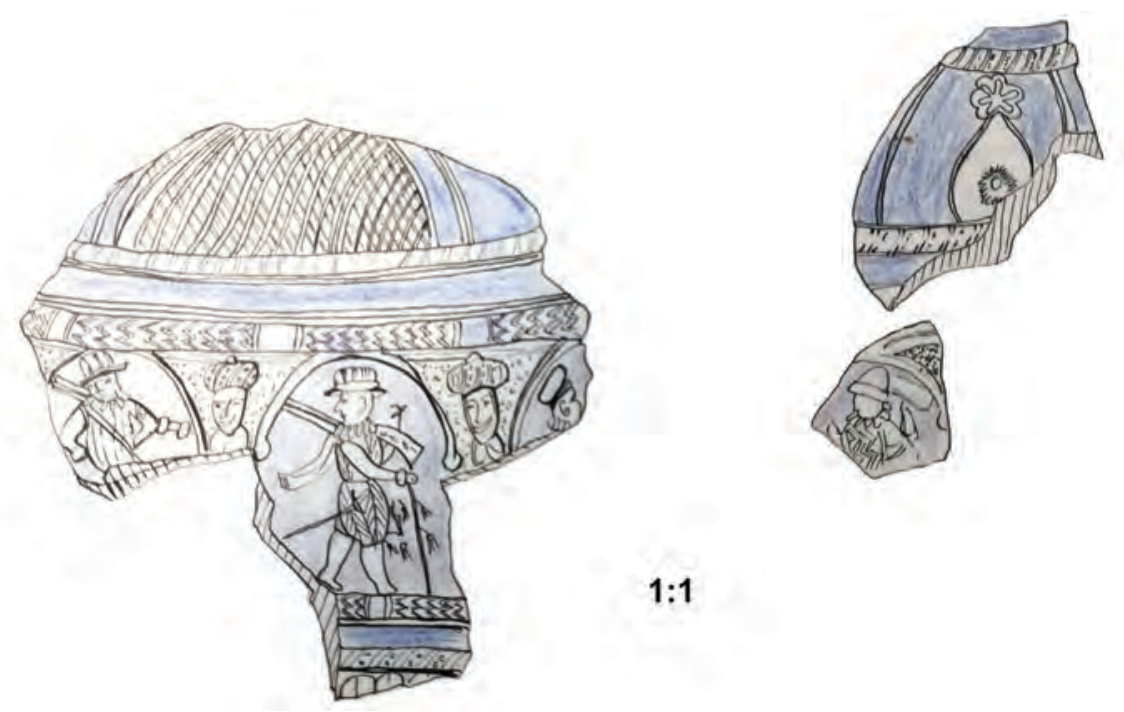

Рис. 9. Зарисовки фрагментов „каменного рейнского товара”. Археологическая полевая документация (собрание Музея Москвы) 


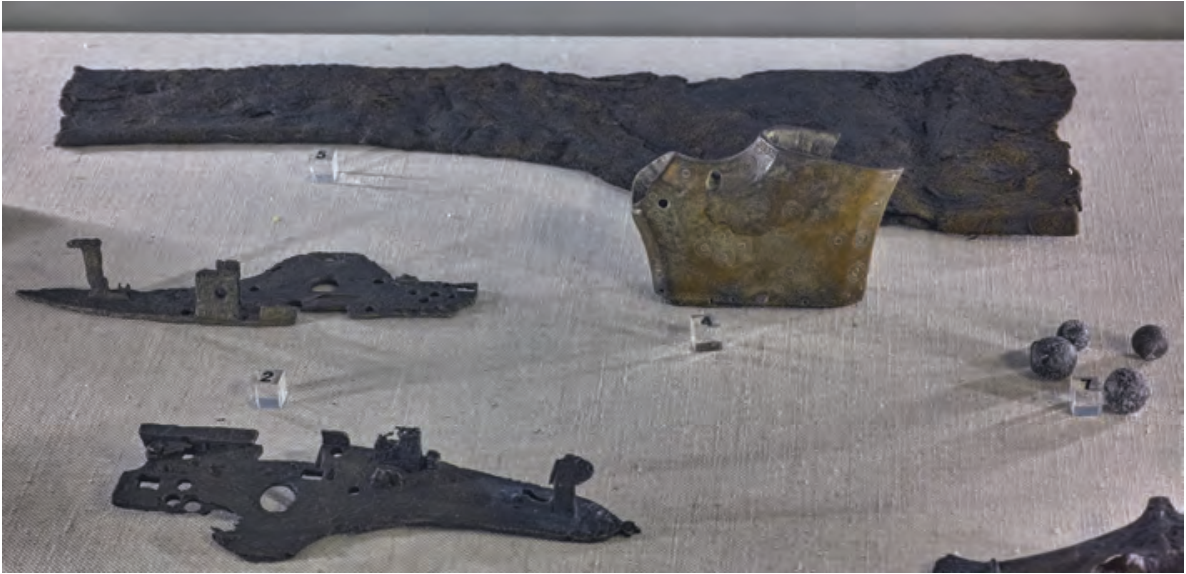

Рис. 10. Предметы вооружения стрельцов Стремянного полка. Экспозиция „Музея археологии Москвы” - Музейного Объединения „Музей Москвы”

бычьим пузырем, как это было у менее обеспеченных горожан. Стоявшие в домах печи были изразцовыми, цвет изразцов соответствовал моде того времени. Милитаристская тематика соответствоваца вкусам хозяев Аомов и вполне могла использоваться как своего рода наглядное пособие Аця первоначального знакомства маленьких мацьчиков с военным делом. Хотя мы и не знаем были $и$ эти изразцовые печи сюжетными рассказами в картинках, но можно полагать, что с их помощью маленьким мальчикам отец мог рассказать о своей службе или даже составить связанное повествование о военных приключениях. Обнаруженные фрагменты привозных глиняных сосудов, так называемый „каменный рейнский товар" 22 свидетельствует, о том, что в быту эти стрельцы не исповедовали изоляционизм. Быт этих мюдей рисует картину заинтересованности в окружающем мире и их открытость некоторым новациям и чужеземным влияниями. Обилие находок фрагментов кожаной обуви подтверждает известный факт, что русские горожане носили в основном кожаную обувь, как взрослые, так и дети. В культурном слое Стремянной слободы сохранились детские глиняные игрушки, фрагменты кожаного мяча и деревяный меч, прекрасно сохранившийся.

22 Музей Москвы, АПА 4/6, Манежная площадь - 1993, г. № 61; Музей Москвы, АПА 4/65, Манежная площадь - 1995, № 88. 
Очевидно, что слобода стрельцов Стремянного полка, расположившаяся возме Кремля на правом берегу реки Неглинной хотя и явцялась районом компактного расселения военных с их семьями, от всего города не изолировалась. Стрельцы были связаны с московским посадом тысячью нитей: бытовых, семейных и служебных. Имущественное положение выше среднего сближало их верхушкой посада. Стремянные стрельцы составлями своеобразный средний кмасс Москвы XVII в. В их быту прослеживается интерес к иноземным предметам, модным веяниям. Их дома комфортны и добротны, их дети сыты и учатся грамоте (не даром в культурном слое Стремянной слободы археологи находили приспособления Аця обучения письму - писала и чернильницы), жены носят ювелирные украшения. ОАнако, не смотря на свои связи с городским населениям, стремянные стрельцы осознают свое особое положение, причастность к чему-то большему чем просто жизнь в городе. Это понимание отразимось, например, в репертуаре сюжетов печных изразцов, которые в отличие от изразцов из Аругих районов Москвы, преимущественно посвящены военному делу: осадам, боям, стрельбе из пушек, штурмам вражеских крепостей. Все это создавало своеобразный образ старой Москвы, в которой военное сословие переплеталось с обыкновенными горожанами и стремецкие слободы явмялись полноправными участниками городской жизни.

\section{BIBLIOGRAFIA}

\section{Źródła archiwalne}

\section{Музей Москвы}

АПА 4/5, Манежная площадь - 1993 г., АПА 4/6, Манежная площадь - 1993 г., АПА 4/65, Манежная площадь - 1995 (Muzey Moskvy, APD 4/5, Manezhnaya ploshchad' - 1993 g., APD 4/6, Manezhnaya ploshchad' - 1993 g., APD 4/65, Manezhnaya ploshchad' - 1995). 


\section{Źródła drukowane}

Пискаревский летописещ, [w:] Полное собрание русских летописей, Москва 1974 (Piskarevskiy letopisets, [w:] Polnoye sobraniyerusskikh letopisey, Moskva 1974).

\section{Opracowania}

Бахрушин С.В., Московский мятеж 1648 года, [w:] Сборник статей в честь Матвея Кузвмича Аюбавского, ПетрограА 1917 (Bakhrushin S.V., Moskovskiy myatezh 1648 goda, [w:] Sbornik stateyv chest' Matveya Kuz'micha Lyubavskogo, Petrograd 1917).

Беляев И., О русском войске в чарствование Михаила Федоровича и после его, до преобразований, сделанньх Петром Великим, Москва 1846 (Belyayev I., O russkom voyske $v$ Tsarstvovaniyemikhaila Fedorovicha i posle yego, do preobrazovaniy, sdelannykh Petrom Velikim, Moskva 1846).

Богословский М.М., Заговор Цьклера, [w:] Сборник статей по русской истории, посвященных С.Ф. Платонову, Петербург 1922 (Bogoslovskiy M.M., Zagovor Tsyklera, [w:] Sbornik statey po russkoy istorii, Posvyashchennykh S.F. Platonovu, Peterburg 1922).

ЗАотников М.Ф., Подьяче Ивановской площади (К истории нотариата Московской Руси), [w:] Сборник статей, посвященных Александру Сергеевичу Ааппо-Аанилевскому, ПетрограА 1916 (Zlotnikov M.F., Pod'yachiye Ivanovskoy ploshchadi (K istorii notariata Moskovskoy Rusi), [w:] Sbornik statey, posvyashchennykh Aleksandrusergeyevichu Lappo-Danilevskomu, Petrograd 1916).

Кивлицкий Е.А., Стрельцьь, [w:] Энииклопедический словарь Брокгауза и Эфрона, Санкт-Петербург 1901, t. 62 (XXXIa) (Статика-Судоустройство) (Kivlitskiy Ye.A., Strel'tsy, [w:] Entsiklopedicheskiyslovar' Brokgauza i Efrona, Sankt-Peterburg 1901, t. 62 (XXXIA) (Statika-Sudoustroystvo).

Малиновский А.Ф., Обозрение Москвы, сост. С.Р. Аолгова, Москва 1992 (Malinovskiy A.F., Obozreniye Moskvy, sost. S.R. Dolgova, Moskva 1992).

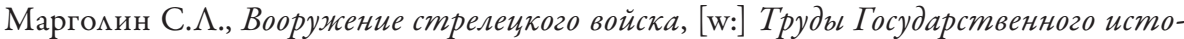
рического музея Вып. XX: Военно-исторический сборник, Москва 1949 (Margolin S.L., Vooruzheniye streletskogo voyska, [w:] Trudy Gosudarstvennogo Istoricheskogo Muzeya, Vyp. XX: Voyenno-istoricheskiy sbornik, Moskva 1949).

Очерки истории СССР. Период феодализма конец XV - начало XVII в., Москва 1955 (Ocherki istorii SSSR. Period feodalizma konets XV-nachalo XVII v., Moskva 1955).

Очерки истории ССCР. Период феодализма. XVII в., Москва 1955 (Ocherki istorii SSSR. Period feodalizma. XVII v., Moskva 1955). 
Чернов А.В., Вооруженньц силь Русского государства в XV-XVII вв. С образования цуентрализованного государства до реформ при Петре I. Краткий очерк, Москва 1954 (Chernov A.V., Vooruzhennyye sily Russkogo gosudarstva v XV-XVII vv. Sobrazovaniya tsentralizovannogo gosudarstva doreform pri Petre I. Kratkiy ocherk, Moskva 1954).

\title{
Максим Моисеев
}

\section{THE SLOBODA OF THE STREMYANNYKH STRELTSY IN MOSCOW FINDINGS FROM ARCHAEOLOGICAL EXCAVATIONS}

\begin{abstract}
Summary. The article is devoted to the Streltsy Stremyannogo Regiment settlement, located in Moscow near the Kremlin on the right bank of the Neglinnaya River. This settlement was excavated by Moscow archaeologists in the 1990s. Scientists found fragments of urban infrastructure, residential buildings, household items. However, these findings did not become the subject of a special study devoted to the life of the Moscow Streltsy. The proposed study is an attempt at a preliminary study of this problem. The paper gives a brief history of the excavations at Manezhnaya Square in 1993-1997, analyzes the basic historiography devoted to the Streltsy. Archaeological field documentation and albums of finds were used for the study. The analysis of the objects allowed us to conclude that the Stremyany Regiment archers were close to the top of the Moscow urban population.
\end{abstract}

Keywords: Moscow, the archers, the citizens, settlements, archeology 
